\title{
Why do More Open Economies Have Bigger Governments?
}

\section{Citation}

Rodrik, Dani. 1998. “Why Do More Open Economies Have Bigger Governments?” Journal of Political Economy 106 (5): 997-1032. https://doi.org/10.1086/250038.

\section{Permanent link}

http://nrs.harvard.edu/urn-3:HUL.InstRepos:41426679

\section{Terms of Use}

This article was downloaded from Harvard University's DASH repository, and is made available under the terms and conditions applicable to Other Posted Material, as set forth at http:// nrs.harvard.edu/urn-3:HUL.InstRepos:dash.current.terms-of-use\#LAA

\section{Share Your Story}

The Harvard community has made this article openly available.

Please share how this access benefits you. Submit a story.

\section{Accessibility}




\section{Why Do More Open Economies Have Bigger Governments?}

\section{Dani Rodrik}

Harvard University

There exists a positive correlation between an economy's exposure to international trade and the size of its government. The correlation holds for most measures of government spending, in low- as well as high-income samples, and is robust to the inclusion of a wide range of controls. One explanation is that government spending plays a risk-reducing role in economies exposed to a significant amount of external risk. The paper provides a range of evidence consistent with this hypothesis. In particular, the relationship between openness and government size is strongest when terms-oftrade risk is highest.

\section{Introduction}

This paper documents a little-known empirical regularity and provides a plausible explanation for it. The regularity consists of a robust association between an economy's exposure to foreign trade and the size of its government. The explanation is that government expenditures are used to provide social insurance against external risk.

The claim that there is a positive association between trade exposure and the scope of government is surprising at first sight. It is widely presumed that the effectiveness of government intervention is lower in economies that are highly integrated with the world economy. This would suggest a negative correlation between the volume of trade and the scope of government. Yet the small, highly open

I thank a referee and an editor for very useful suggestions, Faruk Gül and Richard Zeckhauser for helpful conversations, Chi Yin for excellent research assistance, and participants at several seminars for comments. 
economies of central and northern Europe (e.g., Austria, Netherlands, and Norway) have some of the world's highest shares of government spending in gross domestic product.

The evidence presented in this paper suggests that the European pattern is not an exception. There is a positive and robust partial correlation between openness, as measured by the share of trade in GDP, and the scope of government, as measured by the share of government expenditure in GDP. The correlation is robust in the sense that $(a)$ it is unaffected by the inclusion of other control variables, $(b)$ it exists for measures of government spending drawn from. all available data sets, $(c)$ it prevails for both low- and high-income countries, and $(d)$ it is not an artifact created by outliers. In addition, openness in the early 1960 s is a statistically significant predictor of the expansion of government consumption over the subsequent three decades.

The explanation that best fits the evidence is one that focuses on the role of external risk. Societies seem to demand (and receive) an expanded government role as the price for accepting larger doses of external risk. In other words, government spending appears to provide social insurance in economies subject to external shocks. The central evidence in favor of this explanation comes from regressions in which openness is interacted with two measures of external risk, volatility of the terms of trade and the product concentration of exports. In each case, the interaction term is strongly significant (and the fit of the regression improves), whereas the coefficient on openness per se becomes insignificant or negative. The same result is confirmed in panel regressions with fixed effects for time periods and countries. Hence, unlike other explanations for the correlation between openness and government size, this one receives considerable support.

If the key argument advanced in this paper is valid, a number of ancillary hypotheses follow. First, increases in external risk must lead to greater volatility in domestic income and consumption. Second, a larger share in GDP of government purchases of goods and services must reduce income volatility. Third, the risk-mitigating role of government spending should be displayed most prominently in social security and welfare spending, particularly in the advanced countries that possess the requisite administrative capability to manage social welfare systems. Fourth, causality should run from exposure to external risk to government spending. I provide evidence in favor of each of these propositions. I also provide a simple general equilibrium model that clarifies how government consumption can alleviate exposure to external risk under certain plausible conditions.

An important precursor to this paper is a study by David Cameron 
(1978). In that study, he showed that the best single predictor of the increase in an OECD government's tax revenue (as a share of GDP) between 1960 and 1975 was the economy's openness in 1960 (exports plus imports divided by GDP), with a correlation coefficient of .78. By way of explanation, Cameron argued that more open economies have higher rates of industrial concentration, which tend to foster higher unionization, greater scope for collective bargaining, and stronger labor confederations. These in turn result in larger demands for government transfers-social security, pensions, unemployment insurance, job training, and so forth - which mitigate external risk.

Cameron's study was limited to 18 OECD countries, and his explanation for the finding is probably too specific to be relevant to my 100 plus-country sample. In particular, it may not be plausible to attach such importance to the role of labor organizations in most developing countries. Further, the empirical relationship between openness and government spending holds for government consumption as well, and not just for transfers on which Cameron based his argument. Nonetheless, the hypothesis advanced here is consistent with the idea, considered also by Cameron, that public spending is a risk-reducing instrument on which there is greater reliance in more open economies (see also Bates, Brock, and Tiefenthaler 1991).

The paper is organized as follows. Section II demonstrates the close association between openness and various measures of government spending. Focusing on government consumption, Section III analyzes the robustness of the association as well as tests for (and dismisses) some alternative explanations for the association. Section IV discusses the analytics of the central hypothesis of the paper and provides evidence on both the central and ancillary hypotheses mentioned above. Section $\mathrm{V}$ presents concluding comments.

\section{The Evidence}

Figure 1 shows the simple relationship between openness and government spending in a sample of 23 OECD countries. The vertical axis represents government spending as a share of GDP, excluding interest payments, averaged over the $1990-92$ period. Along the horizontal axis is shown the share of exports plus imports in GDP, averaged over the decade 1980-89. Data are taken from the World Bank's World Data 1995 for government spending and from Penn world tables 5.6 for openness.

The figure reveals an unmistakable positive association between openness and size of government. A semilogarithmic regression 


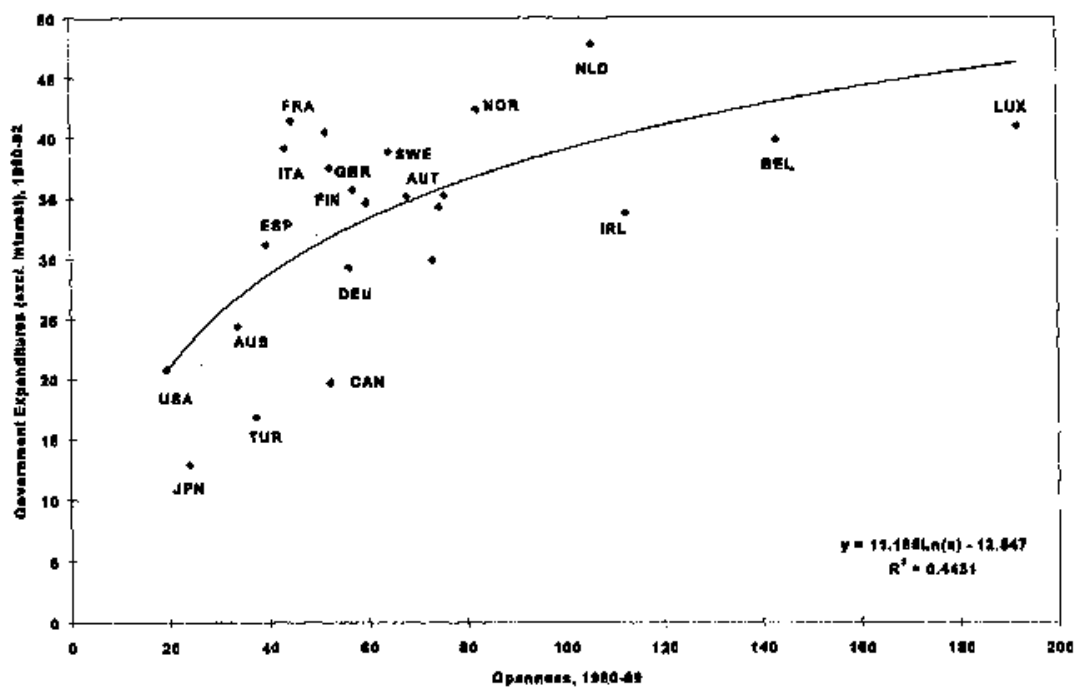

FIG. 1.-Relationship between openness and government expenditures

equation fits the data extremely well, explaining 44 percent of the cross-country variance in government expenditures. The United States and Japan are at one end of the distribution with the lowest trade shares in GDP and (along with Turkey and Canada) the lowest shares of government spending. Luxembourg, Belgium, and the Netherlands are at the other end with very high degrees of openness and large government. Aside from Cameron (1978), earlier studies that have found a correlation between openness and the size of the public sector for the OECD countries include Schmidt (1983) and Saunders and Klau (1985). Figure 1 shows that the correlation continued to hold as of the early $1990 \mathrm{~s}$.

Could the association between openness and the scope of government be a spurious one? The OECD evidence is in fact fragile against alternative hypotheses, such as the following: (a) small countries have larger government shares and are at the same time more open or $(b)$ European countries have large government sectors (for social and cultural reasons) and are also more open because of the presence of a common market among members of the European Union. The small size of the OECD sample rules out testing these various hypotheses meaningfully against each other. When population and a dummy for European countries are added to the regression for the OECD sample, the coefficient on openness remains significant only at the 90 percent level.

I now turn to a broader sample of countries, for which the sample 
size should be less constraining. My preferred measure of government for the larger sample is real government consumption from the Penn world tables. These data have a couple of advantages. They are available for a much larger group of countries than contained in the World Bank data. In addition, they are free of biases arising from cross-country differences in the relative price of government purchases. Two countries with identical levels of real government purchases will appear to have very different shares of government in GDP if the price index for such purchases relative to the GDP deflator differs. The disadvantage is that this measure of government includes only consumption and excludes income transfers and public investment. ${ }^{l}$ I show results for public investment as well in passing, for comparison purposes. Results for more disaggregated levels of government spending will be shown later.

Previous studies on the determinants of government spending in large cross sections of countries have focused on a number of explanatory variables. According to Wagner's law, for example, the demand for government services is income elastic, so that the share of government consumption in GDP is expected to rise with income. Other variables typically considered are demographic and structural indicators (see, e.g., Tait and Heller 1982; Ram 1987; Heller and Diamond 1990). In light of these studies, my benchmark regression includes the following explanatory variables in addition to openness: per capita GDP (GDPSH5xx), the dependency ratio in the population (DEPEND90), the urbanization rate (URBAN90), a dummy for socialist countries (SOC), a dummy for OECD members (OECD), and dummies for geographical regions (LAAM, ASIAE, and SAFRICA for Latin America, East Asia, and sub-Saharan Africa, respectively). These variables were selected after some experimentation to achieve the best overall fit for the regression (but without regard for the significance of the coefficient on openness), within the constraints of data availability. In addition to the variables just discussed, the regressions also include a measure of openness (OPENAVGxxyy), which is the ratio of trade (sum of imports and exports) to GDP, averaged over the prior decade. Aside from the Penn world tables, Barro and Lee (1994) and the World Bank's World Data 1995 are the main sources for the data. More detail on the sources is provided in the Appendix.

\footnotetext{
'Government consumption is defined in the U.N. System of National Accounts as "expenditure, including imputed expenditure, incurred by general government on both individual consumption goods and services and collective consumption services" (United Nations 1993, p. 516]. In view of the difficulty of valuing government services, in practice this item is measured as the cast to the government of the services it provides, including most significantly the wage bill. Some of its main subcategories are public administration, public order, national defense, health, and education.
} 
The dependent variable in most of these regressions is a 3- or 5year average of real government consumption (as a share of GDP) expressed in international prices (CGAVGxxyy). The sample consists of all countries included in the Penn world tables (version 5.6a) for which the requisite data exist. I have excluded observations for which the openness ratio exceeds 200 percent. This cutoff has very little significance for the actual results since it leads to the exclusion of only one observation, that for Hong Kong in the 1990-92 regressions.

Table 1 displays the benchmark results. Columns 1 and 2 relate shares of government consumption in GDP to the previous decade's openness during the two periods 1990-92 and 1985-89. I present results for the 1985-89 period alongside those for 1990-92 because the sample size is larger than in the later period (125 vs. 103 countries). The fit of the regressions is generally good, with an adjusted $R^{2}$ of .43-.46. Contrary to Wagner's law, per capita income enters with a negative sign as a determinant of government consumption in both periods but is statistically significant at the 90 percent level only for 1985-89. The dependency ratio enters positively and is statistically significant at the 99 percent level for both periods. Urbanization enters negatively and is significant at the 95 percent level in 1990-92 and at the 90 percent level in 1985-89. The dummy for socialist countries has a positive coefficient but is not significant at conventional levels. Neither is the dummy for OECD countries. The regional dummies are all statistically significant at the 95 percent level in 1985-89, but not in 1990-92.

I am mainly interested in the estimated coefficient on openness. This coefficient turns out to be positive and highly significant in both cases - at the 99.9 percent level of confidence! The estimated elasticity is a bit larger than 0.2 , implying that a share of total trade (exports plus imports) in GDP that is larger by 10 percent is associated with a share of government consumption in GDP that is higher by 2 percent. Perhaps a better sense of the quantitative significance of this elasticity can be obtained from the following calculation. The median shares of government consumption and openness in the sample are around 18 percent and 60 percent, respectively. A country whose openness is 80 percent (a difference of 33.3 percent from the median, corresponding to an increase in the share of imports by 10 percent of GDP) would be expected to have a level of government consumption that is larger than the median by 1.2 percent of GDP $(0.333 \times 0.2 \times 0.18)$ - an increase from 18 to 19.2 percent of GDP. Whether this is a large or modest effect can be debated, but it is relatively tightly estimated. A 95 percent confidence interval from 


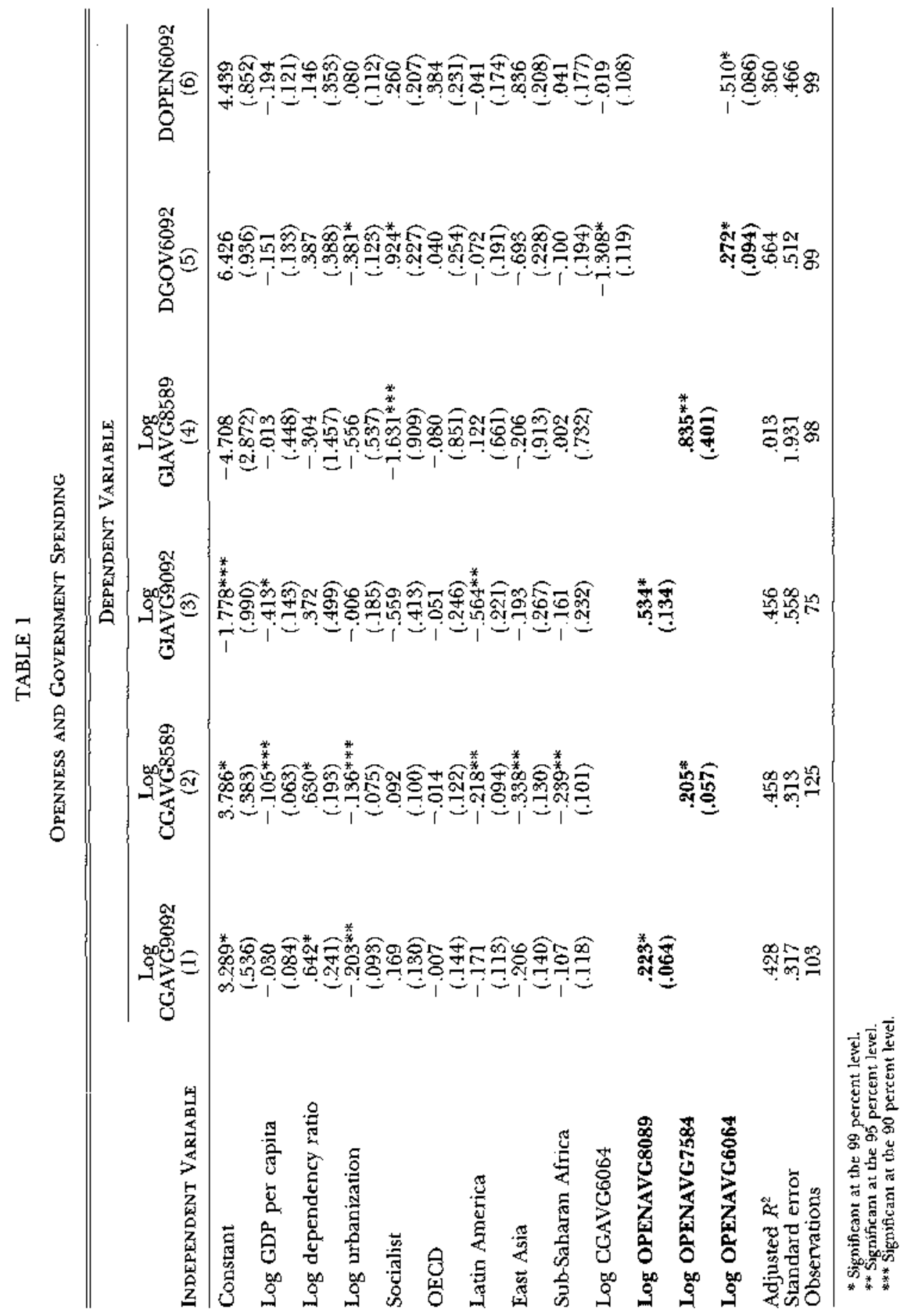


the 1990-92 regression would place the "true" elasticity between 0.095 and 0.351 .

Columns 3 and 4 show regressions in which the dependent variable is now government investment (as a share of GDP). The same set of independent variables as before is used, and results are reported for both 1990-92 and 1985-89. The data, which come from the World Data 1995 of the World Bank, are available for a smaller group of countries and have the relative price problem noted before. Nonetheless the results are interesting and provide a useful complement to those for government consumption. The estimated coefficients on openness are positive and statistically significant as before. Moreover, they are quite a bit larger in magnitude: 0.53 and 0.83 , respectively.

In column 5 of table 1 we can see that openness during the early 1960s can also explain the subsequent increase in government consumption. The dependent variable here is the ratio of the government consumption share in GDP in 1990-92 to that in 1960-64. For most countries, this ratio is greater than one, indicating an expansion of government in the last three decades. The independent variables include the initial share of government consumption as well as initial openness (in 1960-64). The adjusted $R^{2}$ of the regression is quite respectable at .66. The estimated coefficient on initial government is strongly negative, implying a (conditional) convergence effect on government spending. More important from my perspective, the estimated coefficient on initial openness is positive and significant at the 99 percent level. Hence, not only is openness an important determinant of government consumption levels across countries, but openness in the early 1960s turns out to be a significant predictor of the expansion of government consumption in the subsequent three decades.

Column 6 of table 1 repeats the previous regression, replacing the increase in government consumption with the increase in openness as the dependent variable. The point of this exercise is to check whether the previous regressions may have been capturing the effect of government spending on openness rather than vice versa. However, it turns out that the level of government consumption in 196064 has no predictive power for the increase in openness over the following three decades. The estimated coefficient on government consumption in 1960-64 is actually negative (but far from significant). It seems that it is openness early on that determines the subsequent size of government, not the other way around.

Using World Bank data, table 2 shows the relationship between openness and disaggregated categories of government spending. The evidence shows that openness has a statistically significant asso- 


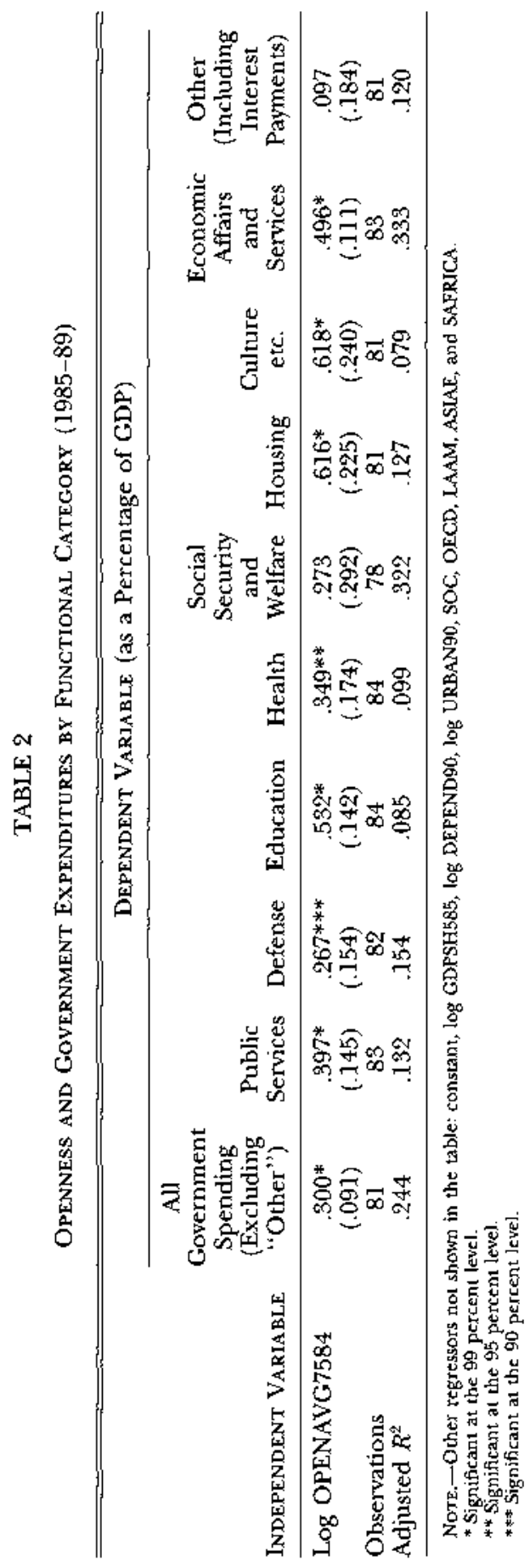


ciation with most types of government spending, including general public services, education, health, housing and community amenities, and economic affairs and services. The estimated coefficients are generally significant at the 99 percent level of confidence. Openness does not enter significantly in the 1985-89 regression for social security and welfare spending, but it does so in the 1990-92 regression (not shown). The only major spending item that does not exhibit a statistically significant correlation with openness in either period is interest payments on the public debt. More detail on the disaggregated data is provided in Rodrik (1997a).

Finally, note that the association between openness and government size apparently exists in all available data sets. These include the Penn world tables and the World Bank's World Data 1995, as noted above. In addition, data on government spending on education from the United Nations Educational, Scientific, and Cultural Organization exhibit a strong positive correlation with openness. The same is true for data on government revenue from the International Monetary Fund as well: more open economies have larger tax / GDP ratios, with other characteristics held constant (see also Tanzi 1992). Government employment (as a share of the labor force) is also positively correlated with openness. See Rodrik (1997a, $1997 b$ ) for studies that cover these additional data sources.

\section{Probing Deeper: Some Hypotheses and Checks of Robustness}

One aspect of robustness has already been discussed: the correlation between exposure to trade and scope of government spans a wide range of data sets and exists for different measures of government size. In this section I shall experiment with various versions of the benchmark regressions reported in table $l$ and in doing so also check for the validity of some possible explanations for the association.

Table 3 reports the results of various experiments with the benchmark specification. I use the 1985-89 equation for government consumption since this covers the largest number of countries (125). Column 1 of table 3 reproduces the coefficient estimate on the openness variable from column 2 of table 1 , for purposes of comparison with later columns. Note that these regressions include the complete set of independent variables considered in table 1, but the estimated coefficients for the other independent variables are not shown in the table to avoid clutter.

Columns 2 and 3 of the table show the results of splitting the sample into two subsamples of roughly equal size according to level of 


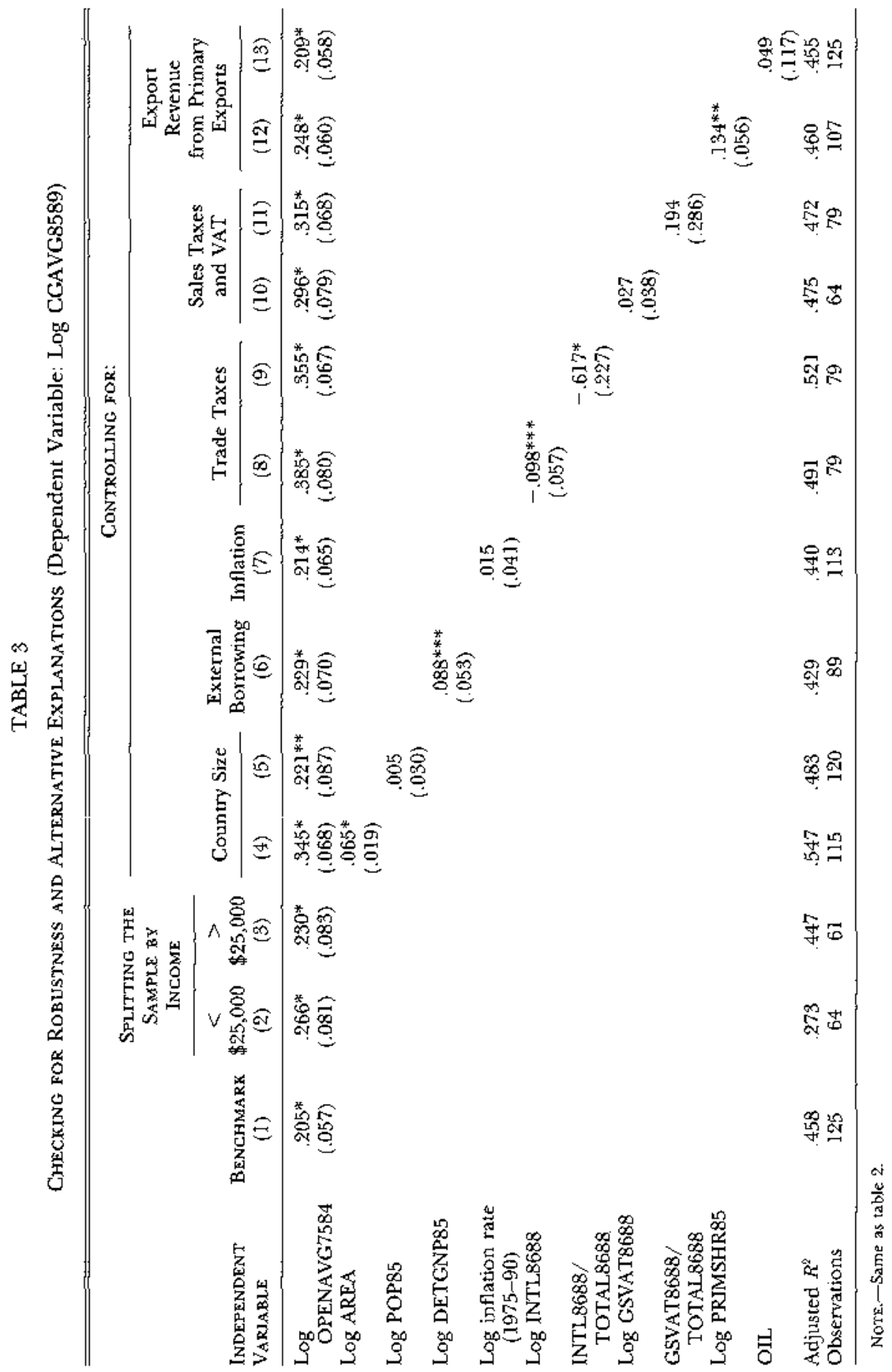


income, using $\$ 2,500$ in 1985 dollars as the cutoff. The coefficient on openness is virtually identical for the two income groups, and it remains statistically significant at the 99 percent level for both subsamples. Hence the relationship between openness and government consumption exists for both the lower- and higher-income halves of the sample.

The remaining columns check whether the coefficient on openness remains stable and statistically significant when additional candidate explanatory variables are included in the regression. Let us first consider the possible influence of country size. Columns 4 and 5 experiment with two different measures of country size: land area (AREA) and population (POP85). (Note that since all variables are included in logs and per capita income is already a regressor, including total GDP is redundant once population has already been added.) The idea behind including these variables is to test whether the observed correlation between openness and government size is due to the following possibility: Assume that the provision of public services is subject to significant indivisibilities; for example, every country, regardless of size, needs one parliament. Then government size as a share of GDP will be negatively correlated with country size (see, e.g., Alesina and Wacziarg 1997). Since openness is negatively correlated with country size as well, the observed association between openness and government spending could be spurious and could arise from the omission of a size variable. However, there is no evidence that something like this is at work here. Both of the size variables enter with a positive sign, and the estimated coefficient on land area is actually highly significant. But in both cases the coefficient on openness remains statistically significant. With land area included, the openness coefficient actually increases significantly in magnitude (to 0.34).

Column 6 checks for the possibility that openness increases government spending by enhancing the economy's ability to borrow from external sources. If the penalty to be suffered by a sovereign debtor (from trade sanctions, say) increases with the economy's dependence on trade, which seems plausible, external credit rationing will tend to be less binding in more open economies. In such economies, the government can borrow more and spend more, if it views spending as inherently desirable. To control for this possibility, the debt/gross national product ratio is included as an independent variable (DETGNP85). The estimated coefficient on the debt/GNP ratio is positive and significant at the 90 percent level, so there is some support for the theoretical prediction. However, the coefficient on openness remains unchanged and highly significant.

Another hypothesis is that more open economies have lower inflation and, because of that, a larger tax base. Under high-inflation 
conditions, the government's tax base erodes both as a result of delays in tax payments in unindexed systems (the Olivera-Tanzi effect) and as a consequence of the shrinkage of the formal sector at the expense of the informal sector. The regression in column 7 includes the average inflation rate during $1975-90$ on the right-hand side to check for this possibility. The estimated coefficient on inflation turns out to be insignificant, whereas the coefficient on openness remains unaffected.

Next consider that trade itself may be a convenient tax handle for governments in poor countries that have difficulty raising taxes from other sources. Openness may then allow for higher levels of government spending by allowing a higher level of tax revenues. Restricting the sample now to developing countries, for which the hypothesis is primarily relevant, let us check whether openness exerts an effect on government consumption once the level of trade taxes is controlled for. Column 8 shows the result of including trade tax revenues (as a share of GDP) as an additional independent variable (INTL8688). This variable covers all revenue from trade sources, including import duties and export taxes. The estimated coefficient on it turns out to be negative (and statistically significant at the 90 percent confidence level). The coefficient on openness increases in magnitude and remains highly significant. While the sign on trade taxes may be surprising, what seems to be going on is the following: governments that raise a lot of revenue from trade (even after one controls for per capita income) tend to have very few other tax handles, and therefore their ability to spend tends to be severely restricted. Further evidence for this interpretation comes from column 9, which includes the share of trade taxes in all tax revenues on the right-hand side (INTL8688/TOTAL8688). The estimated coefficient on this variable is negative and significant at the 99 percent level. Including this particular variable in the regression also results in raising the $t$-statistic on the openness elasticity to above 5 !

A related version of the previous argument is that large trade volumes may help governments collect higher revenues from indirect taxes such as sales taxes and value-added taxes (VAT). In many poor countries, such taxes are collected disproportionately at the border. ${ }^{2}$ To check for this possibility, I control for indirect tax revenues including VAT (both as a share of GDP and as a share of total tax revenues) in columns 10 and 11 . The estimated coefficient on openness remains unaffected.

I also check for the possibility that the correlation is due to resource rents or other revenue derived by the government from export activities. Columns 12 and 13 introduce the share of primary

${ }^{2}$ I am grateful to a referee for making this point. 


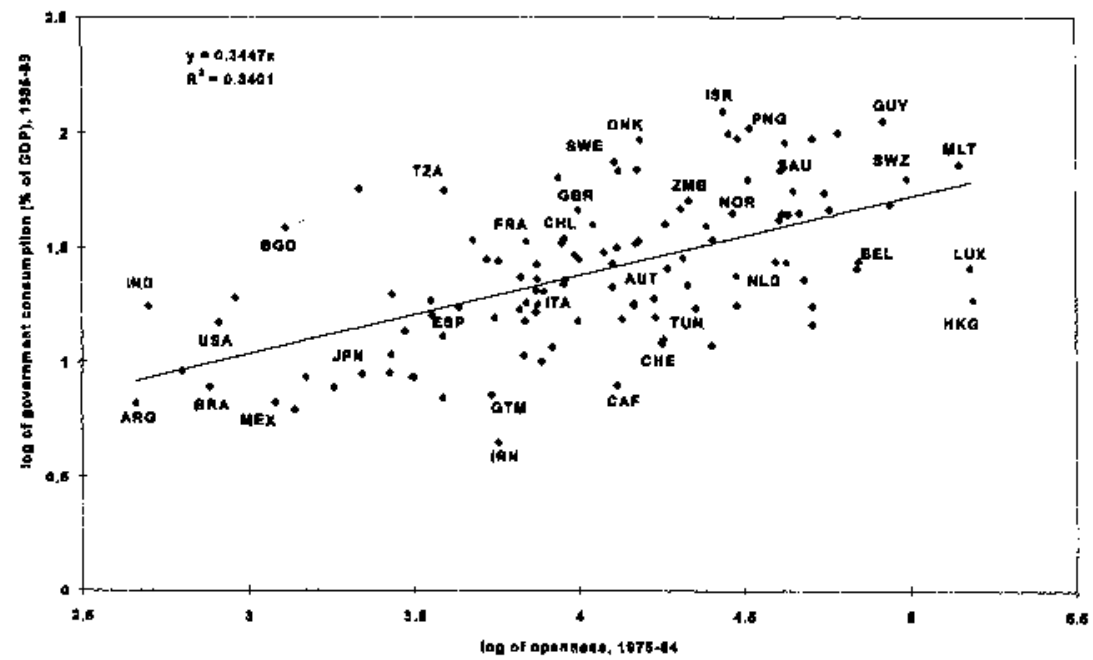

Fig. 2.-Partial relationship between openness and government consumption (when one controls for per capita income, urbanization, dependency ratio, area, and regional dummies).

products in total exports (PRIMSHR85) and a dummy for oilexporting countries (OIL), and in neither case is the coefficient on openness affected. I have also used a direct measure of export tax revenues (not shown), with similar results.

Finally, what about the possibility of outliers? Figure 2 displays the partial relationship between openness and government consumption-partial in the sense that other determinants of government consumption are controlled for--generated by the regression in column 4 of table 3 . There are 115 countries in this figure, and some of them have been identified by country codes to give the reader a sense of where different countries stand. The figure is a good way of summing up what we have learned so far: there is a tight and robust empirical association between openness to trade and government consumption (as a share of GDP) in a large cross section of countries. Further, the figure makes clear that the result is not driven by the presence of outliers: the 115-country sample covers practically the full range of my measures of openness and government consumption.

\section{A Possible Explanation: Social Insurance against External Risk}

Hence the statistical association between openness and government spending appears to be a robust one. It is not a spurious relationship 
generated by omitted variables. Nor is it an artifact of the sample of countries selected or of a specific data source. The question is why this relationship exists.

One plausible answer, which I shall show below is consistent with the evidence, is the following. More open economies have greater exposure to the risks emanating from turbulence in world markets. One can view larger government spending in such economies as performing an insulation function, insofar as the government sector is the "safe" sector (in terms of employment and purchases from the rest of the economy) relative to other activities, and especially compared to tradables. Hence in countries significantly affected by external shocks, the government can mitigate risk by taking command of a larger share of the economy's resources.

To fix ideas, consider the following framework. Divide the economy into three sectors: private tradables, private nontradables, and the government sector. Think of a representative extended household in this economy as having claims on income streams from each of these three types of activities. The larger the share of government consumption in the economy, the larger the share of the household's total income that derives from the government sector. Can a (permanently) higher share of government consumption mitigate the representative household's exposure to external risk in such an economy? And when will it be optimal for the government to reduce risk in this fashion?

Assume that the government sector is the "safe" sector in a sense that will be made more precise empirically later on. Suppose, in the extreme, that employment and incomes in the government sector are stable and uncorrelated with any of the shocks to which the economy is subjected. Under these circumstances, some of the riskiness in the household's income due to external shocks can be mitigated by having a larger government sector. And if the government acts as the agent of households that dislike risk, it will choose to consume a greater share of the society's resources in economies that are subject to greater amounts of external risk. I shall illustrate this argument with a simple model below.

In principle, external risk should be diversifiable for small countries through participation in international capital markets. In practice, this does not appear to be the case. Lewis (1995, p. 1914) summarizes the literature on international portfolio diversification thus: "recent evidence shows that domestic investors continue to hold almost all of their wealth in domestic assets." For the majority of the countries in the sample, the reason may be that full capital market openness conflicts with other objectives of government policy, or that incentive and sovereign risk problems restrict the range and 
extent of financial instruments available to them. For others, the apparent incompleteness of international portfolio diversification remains a puzzle-indeed a central puzzle in the theory of international finance (Lewis 1995). The empirical implications of perfect international consumption risk sharing - that consumption growth rates should be unaffected by country-specific shocks-are usually rejected by the data even for the advanced industrial countries with completely liberalized financial markets (Lewis 1995; Obstfeld 1995).

One might also object that the government's risk-reducing role would be best played through the establishment of a safety net, in which case it would show up mainly in government spending on social security and welfare, and not in government consumption. I shall show below that this prediction is borne out in the case of the more advanced countries, which do have the administrative capacity to manage social welfare systems. In these countries, government consumption is uncorrelated with exposure to external risk, whereas spending on social security and welfare is strongly correlated. But governments in the developing countries that predominate in the cross section appear to rely on a broader set of instrumentalities-m including, notably, public employment-to achieve risk reduction.

Even if one accepts that full diversification through participation in international capital markets is realistically not possible, the story outlined above makes two leaps of faith. One is that economies subject to greater anounts of external risk necessarily experience more risk in total income as well, the latter being what really matters to the representative household. The second is that the government sector is "safe" in the sense that an expansion in it would reduce aggregate income risk. Neither of these propositions is obvious, but I shall present evidence below that suggests that they are both empirically valid.

\section{A. A Simple Model}

Consider an economy that has a fixed supply $x$ of an export good and produces two additional goods: a publicly provided good and a private good. The economy also has a labor endowment normalized to unity, with $\lambda$ employed in the public sector and $1-\lambda$ in the private sector. Let $\pi$ denote the (stochastic) price of the export good in terms of the import good (i.e., the terms of trade). Assume that the export good is not consumed at home and that the import good is not produced domestically. Trade is balanced continuously, so the home economy purchases a quantity $\pi x$ of imports.

Let us treat imports as intermediate goods and assume that they 
increase the productivity of private production domestically. The production function for the private good is taken to be linear in labor and can be written as $\pi x(1-\lambda)$. Note that by making domestic productivity a function of the level of imports, we have captured one plausible channel through which trade risk spills over to the domestic economy. There is strong evidence of such spillovers in the data, as we shall see later (subsection $D$ ). (Expressing private production as a linearly homogeneous production function $f(\pi x, \mathrm{I}-\lambda)$ would not alter any of the qualitative results below, but would add several terms to the algebra.) Finally, the supply of the publicly provided good is given by $h(\lambda)$, with $h^{\prime}>0$ and $h^{\prime \prime}<0$.

The government determines the size of the public sector $(\lambda)$ before the specific realization of $\pi$ is known. We can view this as the optimal determination of the size of the public sector in view of the underlying variability of the terms of trade. For simplicity, let the publicly provided good and the private good be perfect substitutes in consumption. The government's problem is

$$
\max _{\lambda} V(\lambda) \equiv E[u(h(\lambda)+\pi x(1-\lambda))],
$$

where $u(\cdot)$ stands for the utility function of the representative household, with $u^{\prime}(\cdot)>0$ and $u^{\prime \prime}(\cdot)<0$. Let $\pi$ be distributed with mean $\pi_{m}$ and variance $\sigma^{2}$. Taking a second-order Taylor approximation to $u(h(\lambda)+\pi x(1-\lambda))$ around $\pi_{n}$ and taking expectations, we can express $V(\lambda)$ as

$$
\begin{aligned}
V(\lambda) \approx & u\left(h(\lambda)+\pi_{m} x(1-\lambda)\right)+\frac{1}{2} u^{\prime \prime}(h(\lambda) \\
& \left.+\pi_{m} x(1-\lambda)\right)(\mathrm{I}-\lambda)^{2} x^{2} \sigma^{2} .
\end{aligned}
$$

Expected utility is decreasing in the variance of the terms of trade. Define $R=x \sigma$ as our measure of exposure to external risk. The associated first-order condition is

$$
\left[u^{\prime}(\cdot)+\frac{1}{2} u^{\prime \prime \prime}(\cdot)(1-\lambda)^{2} R^{2}\right]\left[h^{\prime}(\lambda)-\pi_{m} x\right]-\frac{1}{2} u^{\prime \prime}(\cdot) R^{2}=0 .
$$

A sufficient condition for the first term in brackets to be positive is that the representative household exhibit "prudence" in consumption (i.e., that $u^{\prime \prime \prime}(\cdot)>0$ ), which we assume. A direct implication is that as a result of exposure to external risk $(R>0)$, the optimal level of $\lambda$ is larger.

Hence consider two economies $\mathrm{A}$ and $\mathrm{B}$, with $R_{\mathrm{A}}=0$ and $R_{\mathrm{B}}>$ 0 , but identical in all other respects. The first-order condition 
for the A economy simplifies to $h^{\prime}\left(\lambda_{A}\right)=\pi_{m} x$. For the B economy, $h^{\prime}\left(\lambda_{\mathrm{B}}\right)<\pi_{m} x$. Since $h^{\prime \prime}(\cdot)<0$, we have $\lambda_{\mathrm{B}}>\lambda_{\mathrm{A}}$.

Standard portfolio arguments suggest that an increase in the riskiness of exports calls for a reallocation of the economy's resources toward the safe activity (government), even when the return to government activities lies below the (mean) return to other activities. ${ }^{3}$ I have shown this result in a model with a fixed supply of exports. In a model in which export supply is variable and exports compete for resources with the government sector, the risk-reducing effect of government consumption would be even more direct and immediate.

\section{B. Empirical Tests of the Central Hypothesis}

A test of the central hypothesis can be carried out by checking whether the relationship between openness and government consumption is stronger in economies that are exposed to greater amounts of external risk. For this we need empirical proxies for exposure to external risk. There are two such measures that I use here.

One is terms-of-trade risk, which is the measure used in the model above. In an economy with no market imperfections, a measure of the volatility of the streams of income associated with fluctuations in the external terms of trade not only would be the theoretically appropriate measure of external risk, but would be the only relevant measure of such risk. More formally, let $x, m$, and $y$ stand for volumes of exports, imports, and GDP, respectively. Let $\pi$ be the natural logarithm of the price of exports relative to imports (the terms of trade). Let the log of the terms of trade follow a random walk, possibly with drift (a hypothesis that cannot be rejected for most countries). The unanticipated component of the income effects of a terms-of-trade change can then be expressed (as a percentage of GDP) as $1 / 2[(x+m) / y](d \pi-\alpha)$, where $\alpha$ is the trend growth rate in the terms of trade. The standard deviation of this is $1 / 2[(x+m) / y] \times$ st.dev. $(d \pi)$. Hence, interacting the measure of openness $([x+m] / y)$ with the standard deviation of the first $(\log )$ differences in the terms of trade gives us (twice) the appropriate measure of external risk.

The second measure I use is a quantity-based measure, and it is an index of the product concentration of exports. More specifically, it is

\footnotetext{
${ }^{3}$ The presence of a complete set of state-contingent markets at home would not affect this conclusion as long as the technology employed in government production was not available to the privace sector. The reason is that excernal risk is not diversifiable domestically.
} 
a Gini-Hirschman index of concentration defined over 239 threedigit standard international trade classification categories of exports, as calculated by the United Nations Conference on Trade and Development. Countries that export only a few commodities are presumably more exposed to external risk than countries with a diversified set of exports, in a way that need not necessarily show in fluctuations in the terms of trade. So the second measure of external risk is generated by interacting openness with this concentration index. In practice, however, the two measures turn out to be very closely related (with a correlation coefficient close to 8 ).

The basic strategy in the next set of regressions, then, is to interact with openness $(a)$ the terms-of-trade variability and $(b)$ the product concentration of exports to see whether the inclusion of these additional variables results in statistically significant coefficients and improves the fit of the regressions. Table 4 shows the results for the 1990-92 sample. Column 1 displays the benchmark regression for government consumption, to facilitate comparison with the new regressions in the rest of the table. (Note that OPENAVG8089 is not in logs in this version of the benchmark, to allow for the inclusion of the new variables both on their own and in interaction with openness.)

Column 2 of the table displays the results when the export concentration index (CI90) is added to the regression, both individually and interacted with openness. Note that the adjusted $R^{2}$ rises somewhat, and as predicted by the risk-mitigating hypothesis, the coefficient on the interaction term is positive and statistically significant at the 95 percent confidence level. Equally important, the coefficient on openness (entered alone) has now become completely insignificant. Hence we have rather clear confirmation that the effect of openness on government consumption is strongest in countries with more concentrated exports.

The results with terms-of-trade risk (TOTDLOGSTD) are even more striking (col. 3). When this variable is included, the improvement in the fit of the regression is sizable (with the adjusted $R^{2}$ rising from .395 to .445 ). The interaction term is significant at the 99 percent level, and the estimated coefficient on openness now turns negative. These results are particularly encouraging in light of the fact that, as discussed above, this particular interaction term is the theoretically appropriate measure of external risk for an open economy. In fact when the terms-of-trade and export concentration measures of risk are included simultaneously in the regression (col. 4), it is terms-of-trade risk that does all the work, despite the high correlation between the two. Results using the I985-89 sample (not shown) are, if anything, stronger: both measures of external risk are statisti- 


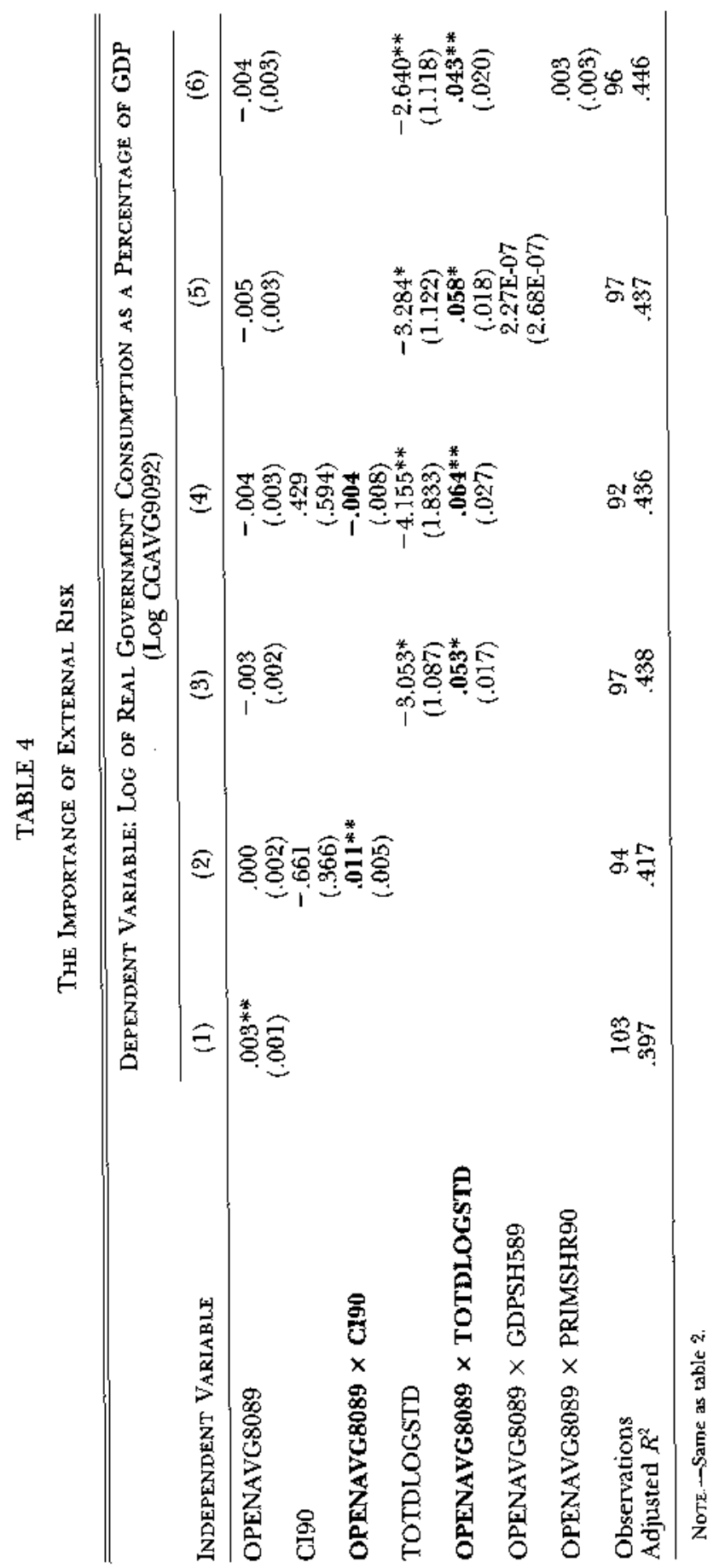


cally significant at the 99 percent level, and once again there is a strong indication that it is terms-of-trade risk that is the operative channel.

Columns 5 and 6 of table 4 check for the possibility that the measures of external risk may be proxying for low income or for greater revenue extraction when exports are made up of predominantly primary resources. Terms-of-trade instability and export concentration are negatively correlated with per capita income and positively correlated with the primary commodity share of exports. The interaction terms could be capturing a nonlinearity in income or rent extraction by the government from primary exports (through marketing boards, government ownership, and other controls on exports). However, when per capita income is interacted with openness and included in the regressions, the results reported above do not change (col. 5). Neither is there a change when the primary share of exports (interacted with openness) is included (col. 6). The coefficients on the external risk variables are robust to the addition of these new terms. Moreover, the findings are unaffected by the inclusion in the regression of all the other variables considered previously in table 3 (results not shown). ${ }^{4}$

Table 5 replicates the results in a panel setting: it shows that past exposure to external risk is a statistically significant determinant of government consumption, even after a full set of period and country fixed effects is introduced. For the purposes of this estimation, I have divided the period from 1960 to I 992 into seven subperiods and calculated averages of government consumption, openness, and terms-of-trade risk for each of these subperiods. The panel regressions are run using both fixed and random effects, as well as first differences. The coefficient on lagged external risk is positive and statistically significant in all specifications but one (where it is borderline insignifcant). The results indicate that the association between exposure to external risk and government size is not a purely cross-sectional one; it exists also in the time series for individual countries.

One way to summarize what has been learned from these exercises is to use the estimated coefficients to ask how much openness matters to government consumption in countries at different points along the distribution of terms-of-trade instability. Consider a country with the mean level of government consumption in the sample (which is around 20 percent). Estimates in column 3 of table 4 sug-

\footnotetext{
"The results on the importance of exposure to external risk in determining government consumption levels have also been confirmed in a subsequent paper by Commander, Davoodi, and Lee (1996), which uses a somewhat different data set and econometric specification.
} 


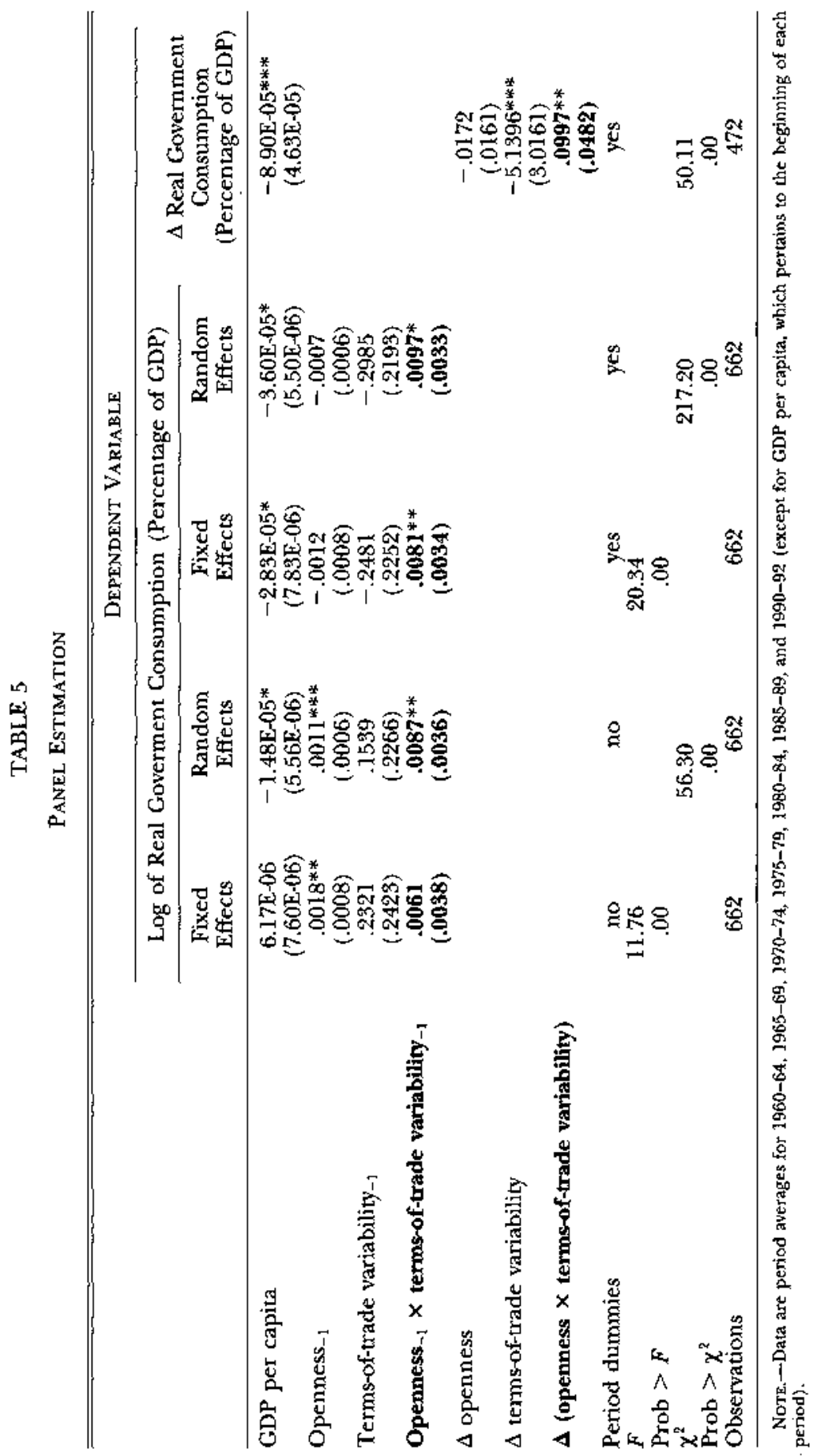


gest that an increase in the share of total trade (exports plus imports) in GDP of 10 percentage points would increase government. consumption by 0.8 percentage points of GDP if that country is located at the mean of the cross-country distribution of terms-of-trade instability. The same increase in openness would lead to an increase in government consumption of I.7 percentage points of GDP if that country experiences terms-of-trade instability one standard deviation above the mean. For a country with terms-of-trade instability one standard deviation below the mean, the impact on government consumption would be virtually nil.

Hence, we can conclude that openness matters to the scope of government because of the role played by external risk. Governments consume a larger share of domestic output in economies subject to greater amounts of external risk. Once external risk is controlled for, openness does not seem to exert an independent effect on government consumption. Put differently, openness appears to work purely through its consequence of exposing the economy to greater amounts of external risk.

\section{The Role of Social Security and Welfare Spending}

If government spending played a risk-mitigating role, we would expect to see this primarily reflected in income transfer programs and in social security and welfare spending. In most developing countries, income transfer schemes tend to be rudimentary for reasons of administrative capacity. Consequently, their governments tend to rely on public employment, in-kind transfers, and public-works programs-all of which show up in government consumption-in order to broaden safety nets. But in advanced countries with social welfare programs in place, it should be primarily spending on social security and welfare that is correlated with exposure to external risk, not government consumption. That is indeed what we find.

Table 6 displays a set of regressions for three separate groups of countries: (i) members of the OECD, (ii) countries with 1985 GDP per capita greater than $\$ 4,500$, and (iii) all countries. For each set of countries, I have run two regressions, one with social security and welfare spending as the dependent variable and the other with govexnment consumption. To make the estimated coefficients comparable across the two specifications, I restrict the sample to countries for which I have data for both types of government spending. (This explains the sample size of 68 in the regressions for "all countries.")

The results are interesting. For each of the three groups of countries, the estimated coefficient on external risk is considerably larger in the social security and welfare regression than in the government 


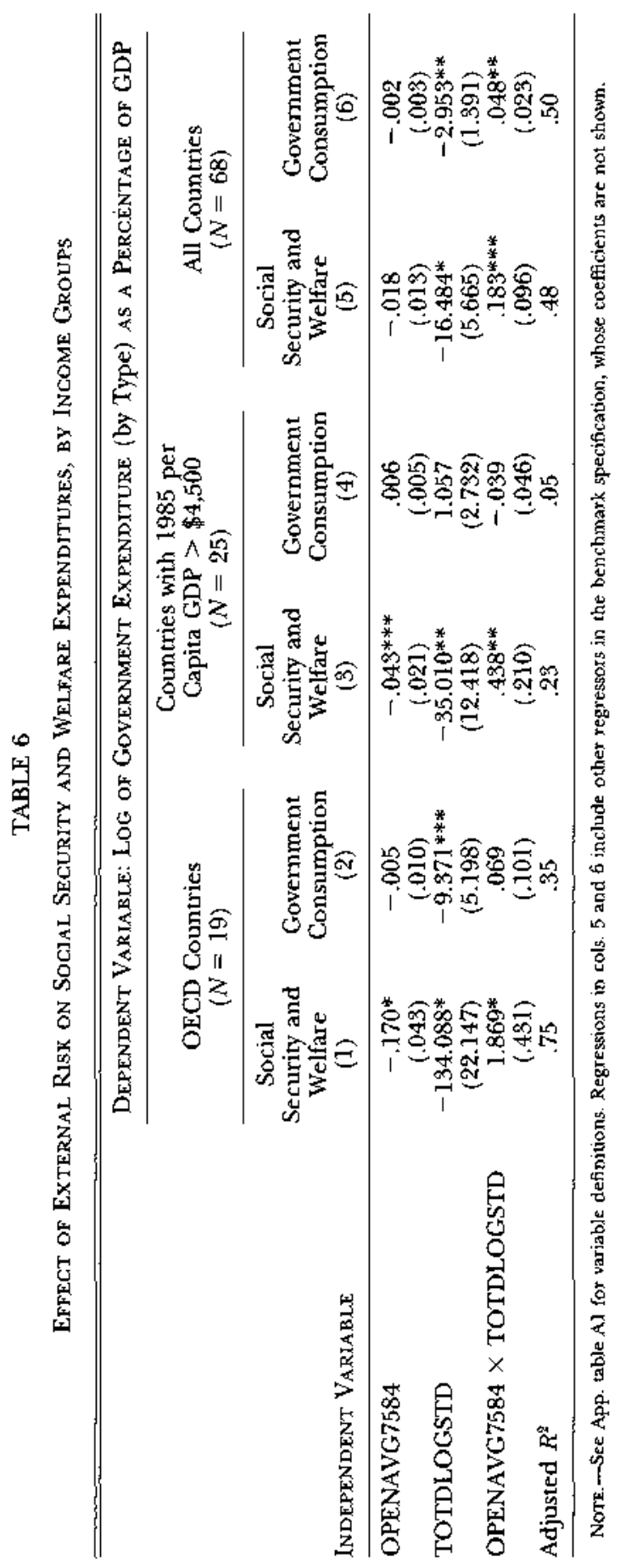


consumption regression. This indicates that spending on social security and welfare is significantly more sensitive to exposure to external risk than government consumption, which is consistent with our theory. ${ }^{5}$ Note, however, that this coefficient becomes smaller as one moves from the high-income to the broader sample of countries, and the precision with which it is estimated becomes lower. This is also plausible since it reflects both the greater difficulty of administering income transfer programs in low-income countries and the greater measurement error. Note finally that exposure to external. risk does not have a statistically significant impact on government. consumption in the OECD or high-income samples. In these samples, it is spending on social security and welfare that correlates with external risk, and not government consumption. Once again, this bears out the theory.

\section{Does Exposure to External Rish Increase Aggregate Risk?}

Let us now return to one of the doubts raised above about the relevance of the hypothesis advanced here. The idea that greater exposure to external risk increases the total risk to which residents of a country are exposed should raise some eyebrows. It is certainly the case that the world economy as a whole is less volatile than the economy of any single country. We can expect the world market to be less risky than any of its constituent parts, thanks to the law of large numbers. Hence it is entirely possible that greater exposure to external risk is accompanied by reduced exposure to domestic sources of risk and that the balance works out in favor of lower risk in aggregate. What goes against this is that openness to trade generally implies specialization in production through the forces of comparative advantage. All else equal, one would expect the production structure to be less diversified in more open economies. In an economy that cannot purchase insurance from the rest of the world, what matters is not the stability of the world economy as a whole, but the stability of the stream of earnings from domestic production. Consequently, whether greater exposure to external risk is accompanied by higher or lower amounts of risk in total is an empirical matter.

Table 7 provides the relevant evidence. I regressed income volatility on the measure of external risk to see whether countries with greater exposure to external risk also tend to experience greater

\footnotetext{
"Removing the OECD countries from the "all countries" sample does not affect the estimated coefficient on external risk (or its level of statistical significance) in col. 5 of table 6 .
} 
TABLE 7

Impact of External Risk on Volatility of InCOME and Consumption $(N=104)$

\begin{tabular}{|c|c|c|c|c|}
\hline \multirow[b]{2}{*}{$\begin{array}{l}\text { INDEPENDENT } \\
\text { VARIABLE }\end{array}$} & \multicolumn{4}{|c|}{ 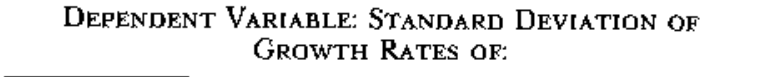 } \\
\hline & $\begin{array}{l}\text { Real GDP } \\
\text { Adusted for } \\
\text { the Terms of } \\
\text { Trade } \\
\text { (1) }\end{array}$ & $\begin{array}{l}\text { Real GDP } \\
\text { (2) }\end{array}$ & $\begin{array}{c}\text { Real } \\
\text { "Private" } \\
\text { GDP } \\
(3)\end{array}$ & $\begin{array}{c}\text { Real } \\
\text { Consumption } \\
(4)\end{array}$ \\
\hline Constant & $\begin{array}{l}.026^{*} \\
(.003)\end{array}$ & $.026^{*}$ & $.025 *$ & $.027^{*}$ \\
\hline GDPSH575 & $\begin{array}{l}-4.22 \mathrm{E}-07 \\
(3.97 \mathrm{E}-07)\end{array}$ & $\begin{array}{l}-3.40 \mathrm{E}-07 \\
(3.64 \mathrm{E}-07)\end{array}$ & $\begin{array}{c}-1.42 \mathrm{E}-07 \\
(3.91 \mathrm{E}-07)\end{array}$ & $\begin{array}{l}-7.53 \mathrm{E}-07 \\
(7.37 \mathrm{E}-07)\end{array}$ \\
\hline SOC & .001 & $\begin{array}{l}.001 \\
(.005)\end{array}$ & .004 & .006 \\
\hline OECD & $-.012^{*}$ & $\begin{aligned}-.012^{*} \\
(.004)\end{aligned}$ & $-.01 .3^{*}$ & $\begin{array}{l}-.013^{* * * *} \\
(.007)\end{array}$ \\
\hline LAAM & $\begin{array}{l}-.006 \\
(.004)\end{array}$ & $\begin{array}{c}-.005 \\
(.003)\end{array}$ & $\begin{array}{l}-.005 \\
(.004)\end{array}$ & $\begin{aligned}-.005 \\
(.004)\end{aligned}$ \\
\hline ASIAE & $\begin{array}{l}-.01 .2 * \\
(.003)\end{array}$ & $\begin{array}{l}-.011 * \\
(.003)\end{array}$ & $\begin{aligned}-.011^{*} \\
(.003)\end{aligned}$ & $\begin{array}{r}-.016^{*} \\
(.006)\end{array}$ \\
\hline SAFRICA & $\begin{array}{l}.001 \\
(.004)\end{array}$ & $\begin{array}{l}.002 \\
(.004)\end{array}$ & $\begin{array}{c}.004 \\
(.004)\end{array}$ & $\begin{array}{c}.006 \\
(.004)\end{array}$ \\
\hline $\begin{array}{l}\text { OPENAVG6092 } \\
\times \text { TOTDLOGSTD } \\
\text { Adjusted } R^{2}\end{array}$ & $\begin{array}{l}.0007^{*} \\
(.0002) \\
.39\end{array}$ & $\begin{array}{l}.0004 * * \\
(.0002) \\
.36\end{array}$ & $\begin{array}{l}.0006^{*} \\
(.0002) \\
.36\end{array}$ & $\begin{array}{l}.0012^{*} \\
(.0003) \\
.48\end{array}$ \\
\hline
\end{tabular}

volatility in income. I used three measures of income: (a) real GDP adjusted for changes in the terms of trade, which gets closest to a measure of real national income; (b) real GDP; and (c) real GDP net of government consumption (which I call "private" GDP). The measure of volatility is the standard deviation of the first $(\log )$ differences of these series over the $1960-90$ period. External risk is captured, as before, by multiplying openness with the standard deviation of the first $(\log )$ differences of the terms of trade.

The results indicate that external risk is positively (and significantly) associated with income volatility for all three measures of income. The estimated coefficients indicate (after suitable transformation) that a 10 percent increase in external risk is accompanied by a 1.0-1.6 percent increase in income risk. This finding is least surprising for the terms-of-trade adjusted GDP; after all, fluctuations in the terms of trade enter this measure of income directly. But GDP and private GDP are not influenced by the terms of trade directly, so these results have real economic content. In particular, they provide justification for a key feature of the model used above, namely that 
external risk spills over to domestic production (see Gavin and Hausmann [1996] for similar results). It is also interesting to note that private GDP appears to be more responsive to external risk than aggregate GDP, if one judges by both the estimated coefficients and their significance levels.

Column 4 of table 7 shows that external risk is a significant determinant of the volatility of private consumption as well. In fact, the estimated coefficient on external risk is largest by far in the regression for consumption volatility, as is the $R^{2}$. This can be read as strong evidence against the presence of consumption smoothing through participation in international capital markets. ${ }^{6}$

\section{E. Can a Higher Level of Government Consumption Stabilize Income?}

Let us next turn to another question raised about the central hypothesis: Can a higher level of government consumption really help stabilize income? ${ }^{7}$ A critical feature of the model discussed previously is that the technologies for private and public production are different. I assumed in particular that the government sector is the safe sector, in which production and incomes are nonstochastic. ${ }^{8}$ In practice, however, government consumption is unstable as well, and it will generally covary with all sources of risk including the terms of trade. Whether public production exhibits stochastic properties different from those of private production is ultimately a question that can be settled only empirically.

A paper by Gali (1994) has documented a robust negative correlation between government size and GDP volatility in the OECD countries. This result is informative for the purposes of this paper but falls short in one respect: Under the maintained hypothesis that government consumption tends to be systematically higher in economies subjected to greater shocks, a cross-country regression that re-

\footnotetext{
${ }^{6}$ Note also that the results reported in table 7 are unchanged when exposure to external risk is instrumented in the fashion described in subsection $F$ below.

${ }^{7}$ Note that the relevant question is not whether countercyclical fiscal policy can stabilize income in Keynesian fashion. It is whether a permanently higher level of government consumption can do so.

${ }^{B}$ This difference can derive in practice from the distinct nature of the goods that are typically considered to be public goods: public administration, law and order, and national defense. It can also result from the divergent incentive and governance structures that characterize production in the two. For example, there is a large literature on government employment practices that suggests that earnings and employment levels in the public sector tend to be either relatively immune to business cycle conditions or purposefully countercyclical (see Kraay and van Rijckeghem 1995; Agenor 1996; Lindauer and Nunberg 1996).
} 
gresses income volatility on the share of government consumption in GDP (as in Galí's paper) is misspecified. In particular, the coefficient on government consumption in such a regression would be biased downward. So I take a different approach here, one that is more consistent with the framework of this paper and relies on the variance-covariance structure of the components of GDP for each individual country.

I begin with some notation. Let $Y_{p}=C+I+(X-M)$ stand for private GDP, $\Pi=p / p^{*}$ for the external terms of trade, $\alpha$ for openness (the share of imports in absorption or, equivalently with balanced trade, the share of exports in GDP), GDP for $Y_{p}+G$, and $\lambda$ for $G / G D P$ (the share of government consumption in GDP). In the absence of net factor payments from abroad, real income can be expressed as

$$
Y=\Pi^{\alpha}\left(Y_{p}+G\right)
$$

and in natural logarithms (with lowercase letters denoting natural logs) as

$$
y=\alpha \pi+(1-\lambda) y_{p}+\lambda g .
$$

The growth rate of real income is in turn

$$
d y=\alpha d \pi+(1-\lambda) d y_{p}+\lambda d g .
$$

Let $\sigma_{y}^{2}$ stand for the variance of the growth rate of real income, which is the measure of income volatility and risk. This can be expressed as

$$
\begin{aligned}
\sigma_{p}^{2}= & \alpha^{2} \sigma_{\pi}^{2}+(1-\lambda)^{2} \sigma_{y_{p}}^{2}+\lambda^{2} \sigma_{g}^{2}+2 \alpha(1-\lambda) \operatorname{cov}\left(d \pi, d y_{p}\right) \\
& +2 \alpha \lambda \operatorname{cov}(d \pi, d g)+2(1-\lambda) \lambda \operatorname{cov}\left(d y_{p}, d g\right),
\end{aligned}
$$

where $\sigma_{s,}^{2}, \sigma_{g}^{2}$, and $\sigma_{n}^{2}$ are the variances of the growth rates of private income, government consumption, and the terms of trade, respectively, and the other terms have the obvious interpretations. Now one could ask how income volatility would respond to a small increase in the share of government consumption, with the variancecovariance structure held constant. If the previous expression is differentiated with respect to $\lambda$,

$$
\begin{aligned}
\frac{1}{2} \frac{d \sigma_{y}^{2}}{d \lambda}= & {\left[\lambda \sigma_{g}^{2}-(\mathrm{I}-\lambda) \sigma_{y_{p}}^{2}\right]+\alpha\left[\operatorname{cov}(d \pi, d g)-\operatorname{cov}\left(d \pi, d y_{p}\right)\right] } \\
& +(1-2 \lambda) \operatorname{cov}\left(d g, d y_{p}\right) .
\end{aligned}
$$

This result states that the consequence depends on the pattern of variances and covariances of the different income streams, as well 
as on the prevailing $\alpha$ and $\lambda$. When government consumption is nonstochastic, equation (1) reduces to

$$
\underset{2}{\mathrm{I}} \frac{d \sigma_{y}^{2}}{d \lambda}=-(1-\lambda) \sigma_{y_{p}}^{2}-\alpha \operatorname{cov}\left(d \pi, d y_{\rho}\right)
$$

which is unambiguously negative provided that $\operatorname{cov}\left(d \pi, d y_{j}\right)$ is positive, as strongly suggested by the results in table 6 . Even when government consumption is stochastic, an increase in $\lambda$ will reduce income volatility provided that $\lambda, \sigma_{g}^{2}$, and $\operatorname{cov}\left(d \pi, d y_{p}\right)$ are sufficiently small.

One can actually use the observed pattern of variances and covariances in the sample to calculate for each country the magnitude and sign of the expression in (1). In other words, one can rely on the historical pattern of shocks experienced by each country to form an idea about how a small increase in the share of government consumption in GDP is likely to affect the volatility of real income in that country. For this purpose, I have calculated the relevant variances and covariances over the 1971-90 period (the period for which terms-of-trade data are available in the World Bank's World Data 1995) for each country with the requisite data. Plugging this data into equation (1) gives a distribution of $d \sigma_{y}^{2} / d \lambda$ for a total of I47 countries. The result is quite striking: a small (permanent) increase in government consumption (as a share of GDP) would result in more stable incomes in the overwhelming majority of countries: 119 out of 147. All advanced industrial countries, without exception, have $d \sigma_{y}^{2} / d \lambda<0$.

A couple of caveats may be in order. First, the calculation is obviously valid only for small changes in $\lambda$. Second, this approach assumes that the pattern of variances and covariances would remain unaffected following an increase in government consumption. This may be defensible for a small enough increase in $\lambda$. Third, there is an endogeneity problem here as well, in that governments that choose the level of $\lambda$ to minimize income risk would set $d \sigma_{y}^{2} / d \lambda=$ 0 , confounding the effect we are looking for. However, this last problem is not severe since governments have many other objectives besides minimizing risk.

Consider, for example, a formulation of the government's planning problem that is more general (but is also more heuristic) than the one laid out above. Suppose that the government cares about both risk and economic activity, $\gamma$. Let us write its objective function as $v\left(\gamma, \sigma_{y}^{2}\right)$, with $\partial v / \partial \gamma>0$ and $\partial v / \partial \sigma_{y}^{2}<0$. The first-order condition for maximizing $v(\cdot)$ is

$$
\left(\frac{\partial v}{\partial \gamma}\right)\left(\frac{d \gamma}{d \lambda}\right)+\left(\frac{\partial v}{\partial \sigma_{y}^{2}}\right)\left(\frac{d \sigma_{y}^{2}}{d \lambda}\right)=0 .
$$


Assume that increasing government size is costly to real activity either because it has to be financed by distortionary (and growthimpeding) taxes or because government production is less efficient; that is, $d y / d \lambda<0$. Then an interior solution will be found at a level of $\lambda$ such that $d \sigma_{j}^{2} / d \lambda<0$. Intuitively, governments will never push the risk-minimizing motive to its maximum limit as long as increasing government size has some cost (see Cashin [1995] and Slemrod [1995] for reviews of the evidence on these costs). Hence in practice we can expect to observe levels of government consumption that fall well short of the point at which no further reductions in income volatility could be achieved.

\section{F. Causality Issues}

Countries differ in their exposure to trade for a number of reasons. One set of reasons has to do with geography: countries that are large and distant from their trade partners will naturally tend to be more self-sufficient and have lower ratios of trade to GDP. But, in addition, exposure to trade is also a function of government policy: countries with high tariff and nontariff barriers to trade will have lower exposure to trade, with all else held constant. The measure of openness, which is the ratio of trade to GDP, conflates these two sets of determinants. One potential problem this raises is that of endogeneity. Could causality be running from government size to external risk exposure rather than the other way around? (While I have used lagged measures of openness in the regressions, this obviously does not fully get around the endogeneity problem.)

I try three related approaches to demonstrating causality, all of which rely on extracting the exogenous component of trade shares. I first create a measure of "natural" openness for each country (NATLOPEN) by regressing the log of OPENAVG7584 on the logs of distance from major trade partners (DIST) and population (POP85), plus a set of country-grouping dummies (SOC, OECD, LAAM, ASIAE, and SAFRICA). This regression has an $R^{2}$ of .71 and yields the expected signs on the coefficients (negative and signifcant on both DIST and POP85). The predicted values from this regression tell how open a country is expected to be on the basis of geographic and other exogenous determinants alone. I call this predicted value NATLOPEN. Using NATLOPEN in lieu of OPENAVG$\mathrm{xxyy}$ is one way of eliminating potential simultaneous-equation bias. Column 1 of table 8 displays the results. Because of the availability of DIST for a smaller number of countries, the sample size is now reduced to 82 . Nonetheless, the fit of the regression is not much 
TABLE 8

EXOGENOUS MEASURES OF EXPOSURE TO EXTERNAL RISK (Dependent Variable: Log CGAVG8589)

\begin{tabular}{|c|c|c|c|}
\hline \multirow[b]{2}{*}{$\begin{array}{l}\text { INDEPENDENT } \\
\text { VARIABLE }\end{array}$} & \multicolumn{3}{|c|}{ Estimation METhOD } \\
\hline & $\begin{array}{c}\text { OLS } \\
\text { NATLOPEN Used } \\
\text { for Openness } \\
(1)\end{array}$ & $\begin{array}{c}\text { OLS } \\
\text { Frankel-Romer } \\
\text { Measure Used for } \\
\text { Openness } \\
\text { (2) }\end{array}$ & $\begin{array}{c}\text { Instrumental } \\
\text { Variables } \\
\text { (3) }\end{array}$ \\
\hline Openness & $\begin{array}{c}-.005 \\
(.004)\end{array}$ & $\begin{array}{l}-.001 \\
(.004)\end{array}$ & $\begin{array}{l}-.006^{* * *} \\
(.003)\end{array}$ \\
\hline TOTDLOGSTD & $\begin{array}{l}-2.899 * * \\
(1.373)\end{array}$ & $\begin{array}{l}-.886 \\
(.722)\end{array}$ & $\begin{array}{c}-4.360^{* * *} \\
(1.102)\end{array}$ \\
\hline $\begin{array}{l}\text { Openness } \times \\
\text { TOTDLOGSTD }\end{array}$ & $\begin{array}{l}.058^{* * *} \\
(.027)\end{array}$ & $\begin{array}{l}.043^{* * *} \\
(.025)\end{array}$ & $\begin{array}{l}.076^{*} \\
(.018)\end{array}$ \\
\hline $\begin{array}{l}\text { Observations } \\
\text { Adiusted } R^{2}\end{array}$ & $\begin{array}{l}82 \\
46\end{array}$ & 116 & 82 \\
\hline Adjusted $\kappa^{n}$ & $.4 b$ & .42 & .60 \\
\hline
\end{tabular}

Note.-Coefficients on other included. regressors are not shown. Col. 3 uses log population (POP85), log distance (DIST), and the exogenous variables in the benchmark specification (alone and interacted with TOTDLOCSTD) as instruments for openness and openness $\times$ TOTDLOGSTD.

affected. More important, the coefficient on the interaction term (NATLOPEN $\times$ TOTDLOGSTD) is positive and statistically signifcant (at the 95 percent level) as before.

Second, I use a measure recently developed by Frankel and Romer (1996) that is available for a larger set of countries. This is an instrument for trade shares based on geographical determinants similar to those employed here. The major difference is that their instrument is constructed using bilateral trade data and a gravity-like estimating framework. Column 2 of table 8 shows the results using the Frankel-Romer instrument for openness. The coefficient on external risk remains statistically significant (but at the 90 percent level).

Finally, an explicit instrumental variables approach using population and distance as instruments (in addition to the other exogenous variables in the benchmark specification) yields the results in column 3. The estimated coefficient on external risk is now larger and significant at the 99 percent level. Note that the set of instruments (distance and population) is as close to being exogenous as one can hope for in cross-country regressions. The validity of this instrument set is easily confirmed using standard tests for overidentifying restrictions.

Hence, the results using the exogenous component of openness are quite similar to those obtained earlier. They confirm the theory about the importance of external risk in determining the size of government consumption. 


\section{Concluding Comments}

The correlation between openness and government size has a number of implications. For one thing, it makes it more difficult to disentangle the relationship between government size and openness, on the one hand, and economic growth, on the other. If one assumes, for example, that openness exerts an independent effect on growth, the typical regression in which growth is regressed on government size would yield a biased coefficient. A similar bias would exist in a regression of growth on trade, if government size has an independent effect on growth.

But there are broader implications as well, with regard to the relationship between markets and governments. These two are often viewed as substitutes. Most types of government intervention, except those related to the provision of public goods, law and order, and property rights, are viewed as inimical to the operation of markets. The international integration of markets is often perceived as undercutting the effectiveness of governmental action at the national level. The findings presented in this paper provide a different perspective, suggesting that there may be a degree of complementarity between markets and governments. The scope of government has been larger, not smaller, in economies taking greater advantage of world markets. Indeed, governments have expanded fastest in the most open economies.

The evidence considered here suggests that the reasons have to do with the provision of social insurance. Openness exerts the strongest influence on government consumption in economies that are subject to the greatest amounts of external risk. Governments appear to have sought to mitigate the exposure to risk by increasing the share of domestic output they consume.

This paper has focused on the cross-country statistical evidence. But there also exist a number of country studies, mostly undertaken by political scientists, that discuss how governments in different parts of the world have responded to the insecurities generated by trade by expanding govermment programs. Katzenstein (1984, 1985), for example, has documented in detail how the small European states such as Sweden, Austria, and the Netherlands "complement[ed] their pursuit of liberalism in the international economy with a strategy of domestic compensation" (1985, p. 47), entailing, among other policies, investment programs, incomes policies, industrial subsidies, and income transfers. The experience of Spain prior to its accession to the European Union in 1986 is also instructive: public expenditure on transfers, social programs, and compensatory programs aimed at regional inequalities expanded greatly prior to the 
mid 1980s, partially in anticipation of the eventual impact of membership in the European Union (see Maravall [1993] for an account). In Chile, which had become increasingly open to trade under the Pinochet regime, the first priority of the incoming democratically elected government in 1990 was "the restoration of benefits for low- and middle-income groups . ... and the development of new social programs targeted at high-risk groups" (Marcel and Solimano 1994, p. 228).

There are few natural experiments in the social sciences, but the experiences of Spain and Chile perhaps come close. The expansion of social welfare spending in both cases-one of them following the death of a dictator and in anticipation of accession to the European Union, the other in the immediate aftermath of transition to democracy following a period of extensive opening up to trade-is illustrative of the hypothesis discussed in this paper. Another case in point, smaller in scope, is the use of trade adjustment assistance programs in the United States. These programs cover extended unemployment benefits and training and relocation subsidies for workers displaced by imports. They have been used (originally in the context of multilateral liberalization in the General Agreement on Tariffs and Trade and more recently in the North American Free Trade Agreement) as an explicit quid pro quo for labor's acquiescence in trade liberalization.

International trade has expanded significantly during the postwar period. Despite some reversals since the 1980 s, so has the scope of government activity in most countries of the world. The findings presented in this paper suggest that this was perhaps no coincidence ${ }^{9}$ For the future, they also suggest that scaling governments down without paying attention to the economic insecurities generated by globalization may actually harm the prospects of maintaining free trade.

\footnotetext{
${ }^{9}$ See Ruggie (1982) for a very useful discussion on this point. Ruggie argues that the international economic liberalism of the postwar period, far from shunting aside the role of government policy, gave it a central role. He calls this "the compromise of embedded liberalism": "The task of postwar institutional reconstruction . . . was to ... devise a framework which would safeguard and even aid the quest for domestic stability without, at the same time, triggering the mutually destructive external consequences that had plagued the interwar period. This was the essence of the embedded liberalism compromise: unlike the economic nationalism of the thirties, it would be multilateral in character; unlike the liberalism of the gold standard and free trade, its multilateralism would be predicated upon domestic interdentionism" (p. $393^{\prime}$; emphasis added). According to Ruggie, the objective of stabilizing domestic employment and output was never meant to be sacrificed at the altar of free trade. Such arguments are reminiscent of Polanyi's (1944) classic book, which argued that unfettered free trade is fundamentaliy incompatible with social order and stability.
} 
TABLE Al

LisT OR VARIAGLES AND SOURCES

\begin{tabular}{|c|c|c|}
\hline Variable & Definition & Source \\
\hline AREA & Land area & Barro and Lee (1994) \\
\hline ASLAE & Dummy for East Asian countries & Barro and Lee (1994) \\
\hline CIxx & Export concentration index & UNCTAD \\
\hline GLAVGxxyy & Government capital expenditures & WD \\
\hline CGAVGxxyy & $\begin{array}{l}\text { Real government consumption as } \\
\text { a percentage of GDP }\end{array}$ & PWT 5.6 \\
\hline DEPENDxx & Dependency ratio & WD \\
\hline DETGNP85 & Debt/GNP racio, 1985 & WD \\
\hline DGOV6092 & CGAVG9092/CGAVG6064 & PWT5.6 \\
\hline DIST & $\begin{array}{l}\text { Geographical distance from } 20 \\
\text { major world exporters }\end{array}$ & Barro and Lee (1994) \\
\hline DOPEN6092 & OPENAVG9092/OPENAVG6064 & PWT5.6 \\
\hline GDPSH5xx & Real per capita GDP & Barro and Lee (1994) \\
\hline GSVAT8688 & $\begin{array}{l}\text { Indirect tax revenues on goods } \\
\text { and services and VAT }\end{array}$ & FAD \\
\hline IN'TL8688 & Taxes on international trade & FAD \\
\hline LAAM & $\begin{array}{l}\text { Dummy for Latin American coun- } \\
\text { tries }\end{array}$ & Barro and Lee (1994) \\
\hline NATLOPEN & $\begin{array}{l}\text { "Natural" openness: exogenous } \\
\text { component of OPENAVG7584 }\end{array}$ & $\begin{array}{l}\text { Computed from Barro } \\
\text { and Lee (1994) and } \\
\text { WD }\end{array}$ \\
\hline OECD & Dummy for OECD countries & \\
\hline OIL & Dummy for oil exporters & \\
\hline OPENAVGxxyy & $\begin{array}{l}\text { Exports plus imports divided by } \\
\text { GDP }\end{array}$ & PWT5.6 \\
\hline POPxx & Population & WD \\
\hline PRIMSHRxx & $\begin{array}{l}\text { Share of primary exports in total } \\
\text { exports }\end{array}$ & WD \\
\hline SAFRICA & $\begin{array}{l}\text { Dummy for sub-Saharan African } \\
\text { countries }\end{array}$ & Barro and Lee (1994) \\
\hline $\mathrm{SOC}$ & Dummy for socialist countries & Sachs and Warner (1995) \\
\hline TOTAL8688 & $\begin{array}{l}\text { Total tax revenue as a share of } \\
\text { GDP, } 1986-88 \text { average }\end{array}$ & FAD \\
\hline TOTDLOGSTD & $\begin{array}{l}\text { Standard deviation of log differ- } \\
\text { ences in terms of trade, } 1971- \\
90\end{array}$ & WD \\
\hline URBANxx & Urbanization rate & WD \\
\hline
\end{tabular}

NoTe. - xx tefers to year $19 x x$, and xxyy refers to an average during $19 x x-19 y y$ (unless specified otherwist). Al government expenditure and revenue data are expressed as a percentage of GDP or GNP. PWT 5.6 stands for Penn world tables 5.6; WD for World Data 1995 (World Bank); FAD for the Fiscal Affajrs Department of the Incernational Monetary Fund; UNCTAD for Handbook of Internationd Trode and Development Statistics of UNCTAD, vatious issues. 


\section{References}

Agenor, Pierre-Richard. "The Labor Market and Economic Adjustment." IMF Staff Papers 43 (June 1996): 261-335.

Alesina, Alberto, and Wacziarg, Romain. "Openness, Country Size, and the Government." Working Paper no. 6024. Cambridge, Mass.: NBER, May 1997.

Barro, Robert J., and Lee, Jong-Wha. "Data Set for a Panel of 138 Countries." Manuscript. Cambridge, Mass.: Harvard Univ., January 1994.

Bates, Robert H.; Brock, Philip L.; and Tiefenthaler, Jill. "Risk and Trade Regimes: Another Exploration." Internat. Organization 45 (Winter 1991): $1-18$.

Cameron, David R. "The Expansion of the Public Economy: A Comparative Analysis." American Polit. Sci. Rev. 72 (December 1978): 1243-61.

Cashin, Paul. "Government Spending, Taxes, and Economic Growth." IMF Staff Papers 42 (June 1995): 237-69.

Commander, Simon; Davoodi, Hamid; and Lee, Una J. "The Causes and Consequences of Government for Growth and Well-Being. ${ }^{11}$ Manuscript. Washington: World Bank, December 1996.

Frankel, Jeffrey A., and Romer, David. "Trade and Growth: An Empirical Investigation." Working Paper no. 5476. Cambridge, Mass.: NBER, March 1996.

Galí, Jordi. "Government Size and Macroeconomic Stability." European Econ. Reu. 38 (January 1994): 117-32.

Gavin, Michael, and Hausmann, Ricardo. "Sources of Macroeconomic Volatility in Developing Economies." Manuscript. Washington: Inter-American Development Bank, February 1996.

Heller, Peter S., and Diamond, Jack. International Comparisons of Government Expenditure Revisited: The Developing Countries, 1975-86. Occasional Paper no. 69. Washington: Internat. Monetary Fund, April 1990.

Katzenstein, Peter J. Corporatism and Change: Austria, Stuitzerland, and the Politics of Industry. Ithaca, N.Y.: Cornell Univ. Press, 1984.

-_. Small States in World Markets: Industrial Policy in Europe. Ithaca, N.Y.: Cornell Univ. Press, 1985.

Kraay, Aart, and van Rijckeghem, Caroline. "Employment and Wages in the Public Sector - a Cross-Country Study." Working paper. Washington: Internat. Monetary Fund, July 1995.

Lewis, Karen K. "Puzzles in International Financial Markets." In Handbook of International Economics, vol. 3, edited by Gene Grossman and Kenneth Rogoff. Amsterdam: North-Holland, I995.

Lindauer, David, and Nunberg, Barbara. Rehabilitating Government: Pay and Employment Reform in Africa. Avebury, U.K: Aldershot, 1996.

Maravall, José Maria. "Politics and Policy: Economic Reforms in Southern Europe." In Economic Reforms in New Democracies: A Social-Democratic Approach, edited by Luiz Carlos Bresser Pereira, José Maria Maravall, and Adam Przeworski. New York: Cambridge Univ. Press, 1993.

Marcel, Mario, and Solimano, Andres. "The Distribution of Income and Economic Adjustment." In The Chilean Economy: Poligy Lessons and Chatlenges, edited by Barry Bosworth, Rudiger Dornbusch, and Raul Laban. Washington: Brookings Inst., 1994.

Obstfeld, Maurice. "International Capital Mobility in the 1990s." In Understanding Interdependence: The Macroeconomics of the Open Economy, edited by Peter B. Kenen. Princeton, N.J.: Princeton Univ. Press, 1995. 
Polanyi, Karl. The Great Transformation. Boston: Beacon, 1944.

Ram, Rati. "Wagner's Hypothesis in Time-Series and Cross-Section Perspectives: Evidence from 'Real' Data for 115 Countries." Rev. Econ. and Statis. 69 (May 1987): 194-204.

Rodrik, Dani. "International Trade and Big Government." In International Trade and Finance: New Frontiers for Research: Essays in Honor of Peter $B$. Kenen, edited by Benjamin J. Cohen. New York: Cambridge Univ. Press, 1997. (a)

—. "What Drives Public Employment?" Working Paper no. 6I4l. Cambridge, Mass.: NBER, August 1997. (b)

Ruggie, John Gerard. "International Regimes, Transactions, and Change: Embedded Liberalism in the Postwar Economic Order." Intermat. Organization 36 (Spring 1982): 379-415.

Sach, Jeffrey, and Warner, Andrew M. "Economic Reform and the Process of Global Integration." Brookings Papers Econ. Activity, no. 1 (1995), pp. $1-95$.

Saunders, Peter, and Klau, Friedrich. "The Role of the Public Sector: Causes and Consequences of the Growth of Government." OECD Econ. Studies, no. 4 (Spring 1985), pp. 5-239.

Schmidt, Manfred G. "The Growth of the Tax State: The Industrial Democracies, 1950-1978." In Why Governments Grow: Measuring Public Sector Size, edited by Charles Lewis Taylor. Beverly Hills, Catif:: Sage, 1983.

Slemrod, Joel. "What Do Cross-Country Studies Teach about Government Involvement, Prosperity and Economic Growth?' Brookings Papers Econ. Activity, no. 2 (1995), pp. 373-415.

Tait, Alan A., and Heller, Peter S. International Comparisons of Government Expenditure. Occasional Paper no. 10. Washington: Internat. Monetary Fund, April 1982.

Tanzi, Vito. "Structural Factors and Tax Revenue in Developing Countries: A Decade of Evidence." In Open Economies: Structural Adjustment and Agriculture, edited by Ian Goldin and L. Alan Winters. Cambridge: Cambridge Univ. Press, I992.

United Nations. System of National Accounts, 1993. New York: United Nations, 1993. 